\title{
Does training policy help to attract, retain and develop valuable human resources? Analysis from the Mondragon case
}

\author{
IMANOL BASTERRETXEA and ENEKA ALBIZU \\ University of the Basque Country, UPV/EHU, Spain
}

This is an electronic version of the accepted paper in the journal:

Advances in the Economic Economic Analysis of Participatory and LaborManaged Firms, Volume. 12

Copyright of the manuscript is assigned to Emerald Group Publishing Limited.

Please, cite this article as:

Basterretxea, I and Albizu, E. (2011): "Does training policy help to attract, retain and develop valuable human resources? Analysis from the Mondragon case", Advances in the Economic Analysis of Participatory and Labor-Managed Firms. Volume. 12. Emerald Group Publishing Limited, pp. $231-260$.

The final published paper is available at http://www.emeraldinsight.com/books.htm?chapterid=1953578

\footnotetext{
1 Imanol Basterretxea (Corresponding author): Tel.: +34 946013868. E-mail address: imanol.basterretxea@ehu.es. Postal address: Universidad del País Vasco. Facultad de Ciencias Económicas y Empresariales. Avda. Lehendakari Aguirre, no 83. 48015 Bilbao (Spain). Eneka Albizu: Tel.: +34 946013119. E-mail address: eneka.albizu@ehu.es. Postal address: Universidad del País Vasco. EU Relaciones Laborales. B ${ }^{\circ}$ Sarriena s/n. 48940 Leioa (Spain).
} 


\begin{abstract}
Purpose - The aim of this article is to ascertain the degree to which a training policy developed through corporate training centers is recognized as a source of competitive advantage for attracting, developing and retaining valuable staff.

Design/methodology/approach - The fieldwork is based on a survey of Human Resource managers from 66 cooperatives of the Spanish Mondragon cooperative group.

Findings - The empirical test carried out confirms that Mondragon's training policy, backed up by its corporate training centers, is perceived by HR managers as a tool that provides advantages to attract, develop and retain valuable human resources. The results also suggest that those advantages are more moderate than has been cited in classic literature on Mondragon.

Practical implications - The results of this study can be helpful for the growing number of companies choosing to create and reinforce corporate training centers. The link between training policy and the perceived ability to attract and retain valuable employees showed in this case, can also be helpful for other companies that, as Mondragon, face limitations in wage policy.

Originality/value - This paper contributes to the literature on the educational fabric of Mondragon adding updated empirical evidence and incorporating the point of view of HR managers of the group's cooperatives.

With respect to the contribution of this paper to the literature on training policy, the paper's findings, in particular those regarding the effect of training on worker attraction and retention, add empirical evidence to the few studies on the subject.
\end{abstract}

\title{
Keywords:
}

Training; Employee attraction; Employee retention; Development; Turnover; Mondragon;

Article type: Research paper

JEL codes: M12; M53; M54 


\section{Introduction}

In a business environment in which people, with their knowledge, skills, experience and motivation, are counted as a resource with great potential for generating sustainable competitive advantages, the war for talent acquires an increasingly sharper profile. Among the different HR policies designed within this competitive environment to attract, develop and retain valuable staff, training policy has gained in prominence over recent years, with a growing number of companies choosing to bolster their internal training structures.

As shown in table 1, 15\% of European companies with more than 10 employees that provide continuous training have their own training centers (Cedefop, 2010; p. 37). A comparison of the 1999 and 2005 figures shows that the percentage of companies with their own training centers increased in most European countries (see table 1).

Table 1.- Businesses with more than ten employees with a training center in 1999 and 2005

\begin{tabular}{|l|c|c|c|c|c|c|c|c|c|c|c|c|c|c|c|c|c|c|c|}
\hline & $\mathbf{F}$ & $\mathbf{E}$ & $\mathbf{S}$ & $\mathbf{N}$ & $\mathbf{H}$ & $\mathbf{E}$ & $\mathbf{C}$ & $\mathbf{D}$ & $\mathbf{F}$ & $\mathbf{L}$ & $\mathbf{P}$ & $\mathbf{R}$ & $\mathbf{L}$ & $\mathbf{I}$ & $\mathbf{P}$ & $\mathbf{E}$ & $\mathbf{B}$ & $\mathbf{L}$ & $\mathbf{S}$ \\
& $\mathbf{I}$ & $\mathbf{L}$ & $\mathbf{E}$ & $\mathbf{L}$ & $\mathbf{U}$ & $\mathbf{E}$ & $\mathbf{Z}$ & $\mathbf{E}$ & $\mathbf{R}$ & $\mathbf{T}$ & $\mathbf{L}$ & $\mathbf{O}$ & $\mathbf{V}$ & $\mathbf{T}$ & $\mathbf{T}$ & $\mathbf{S}$ & $\mathbf{G}$ & $\mathbf{U}$ & $\mathbf{I}$ \\
\hline $\mathbf{1 9 9 9}(\boldsymbol{\%})$ & 1 & 4 & & & & & & & & & & & & & & & & & \\
\hline $\mathbf{2 0 0 5}(\%)$ & 8 & 23 & 11 & 9 & 4 & 6 & 9 & 7 & 15 & 6 & 4 & 13 & 11 & 32 & 21 & 21 & 16 & 25 & 7 \\
\hline $\begin{array}{l}\text { Difference in \% } \\
\text { points }\end{array}$ & -6 & -5 & -5 & -1 & 0 & 1 & 2 & 2 & 2 & 2 & 2 & 4 & 6 & 7 & 7 & 8 & 9 & 9 & 3 \\
\hline
\end{tabular}

Source: CEDEFOP (2010, p.36)

This percentage rises to $34 \%$ in the case of companies with more than 250 employees. In order to underline the bigger strategic role given to those corporate training centers, many of them have adopted the name of corporate universities ${ }^{2}$.

This growth in the number of companies that opt to create and reinforce corporate training centers, as well as the substantial economic resources devoted to this end, contrast with the scarcity of investigations designed to clarify the degree to which these training centers can bring advantages to their companies in terms of attracting, developing and keeping valuable staff.

The present study concentrates on the case of one of the main Spanish business groups (Mondragon Cooperative Group) that has historically stood out for its firm commitment to the creation and consolidation of corporate training centers.

The phenomenon of cooperative business development led by Mondragon, unmatched at a world level, has been receiving attention by researchers from different areas since the 1970's. The central question the research set out to answer was: what lies at the root of the success of this business group? According to several authors, there are different (though not mutually exclusive) reasons that explain the overall success of the

2 In the U.S. there is a growing number of corporate universities in virtually all sectors. American Express, Apple, Bell Atlantic, Disney, Ford, General Motors, Intel, Harley Davidson, McDonalds and Sun Microsystems are just some of these companies with corporate universities. In recent years, major European firms such as AXA, Bayard Press, Bouygues, Cap Gemini, Ernst \& Young, Daimler, Heineken, Lufthansa, Siemens and Schneider Electric have also strengthened their corporate training centers by adopting the corporate university name. 
experience.

The people who make up this business group, cooperative members in the main, in combination with the corporation's training policy, are understood by certain researchers to be one of the reasons for this cooperative business success (Agirre, 2001; Asua, 1988; Aranzadi, 2003; Bradley and Gelb, 1985; Campos, 2005; Chaves, 2003; Ellerman, 1984; Hoover, 1992; Meek and Woodworth, 1990; Morris, 1992; Thomas and Logan, 1991). Other reasons for success mentioned by the literature are also linked to corporate training policy: the existence of better managers and the development of ingroup management tools (Albizu and Basterretxea, 1998; Basterretxea and Albizu, 2010a; Charterina, Albizu and Landeta, 2007; Cheney, 1999; Clamp, 2000, 2003; Jacobsen, 2001; Logan, 1988; Smith, 2001; Thomas and Logan, 1982; Whyte and Whyte, 1989) and corporate cooperative culture (Aranzadi, 2003; Bradley and Gelb, 1985; Cheney, 1999; Smith, 2001).

The objective of this research work is to ascertain the degree to which corporate training centers today act as a source of perceived competitive advantage for Mondragon. We feel this study might be of interest to HR managers and heads of training in companies and entities that, like Mondragon, face constraints in their pay policy which stand in the way of competing through wages in the fight to attract and hold on to valuable staff. In addition, this investigation can throw some light on the debate around the creation of training structures by companies, constituting a new step forward in research on training policy as a source of competitive advantage.

This paper provides an update of the work previously carried out on the training structure of Mondragon. Most of the previous analyses (Asua, 1988; Bradley and Gelb, 1985; Meek and Woodworth, 1990; Whyte and Whyte, 1991) portray the educational fabric of Mondragon in the 70's and 80's. Therefore, they do not discuss several important strategic decisions related to the group's training policy during the last two decades: most notably, the creation of Mondragon University and Otalora, the management training centre. Besides, this paper differs from previous studies in the methodology used. While previous studies are mainly qualitative, based on opinions and data from a reduced number of managers of the corporate offices and some individual cooperatives, our survey offers conclusions based on a questionnaire completed by a representative sample of Mondragon HR managers.

Regarding the structure of this paper, an introduction to the research is followed by a review of works that analyze training policy as a stimulus to attract, develop and retain valuable workers. The third part is devoted to a brief presentation of Mondragon and its training policy, followed in the fourth part by an explanation of the methodology employed in the investigation. Part five sets out the main results of the fieldwork. The sixth part is given over to discussion and also looks into the contributions that this investigation makes with regard to business practice. We finish the paper by pointing out the limitations of the study.

\section{The value of talent}

The staff of a company, with their knowledge, skills, experience and motivation, are regarded as one of the most powerful resources for generating sustainable competitive advantages (Bayo and Merino, 2000, 2001; Mueller, 1996; Wright, McManaman and McWilliams, 1994), especially in high performance organizations (Barron, 2008). This is especially true in the managerial and technical labor markets, where growing investments in technologies and high-standard machinery modify working methods and increase the need for a skilled workforce. 
Having valuable human resources, however, is no guarantee of obtaining competitive advantages unless such resources are scarce (Barney and Wright, 1998).

The condition of scarcity stems from the heterogeneity of human resources. People differ in their abilities, knowledge and attitudes and, consequently, in their contribution to the companies where they work (Wright et al., 1994). Within any labor pool, differences exist between individuals in terms of job-related skills and abilities (Barney and Wright, 1998) and it is hard to attract and keep people who guarantee highperformance levels in the organization.

The war for talent is therefore a core concern for most firms. Effective strategies are nowadays being sought in order to achieve competitive advantages based on talent attraction and retention (Fegley, 2006).

In addition, employees are adopting the philosophy that their job security lies in their employability, rather than in their employment. Talented workers with valuable skills expect employers to continually upgrade these skills, knowledge and ability. Organizations that focus on developing talent will be in a stronger position to retain key employees (Boxall and Purcell, 2003; Capelli, 2008).

Several recent investigations have dealt with the influence of training and development on a firm's capacity to attract, retain and develop valuable employees. Fey, Björkman and Pavlovskaya (2000), based on data from 101 foreign firms operating in Russia, find that providing non-technical training is positively associated with a higher degree of development, motivation and retention of managers.

A survey conducted by Hay Group (Hay, 2002) among 330 companies in 50 countries shows that lack of training and poor career development is resulting in employees leaving and moving on. In the same sense, the results of the research done by ExecEd and MSGM's ISL on Australian managers (Hughes, 2009) suggest that management development and training programs are effective strategies for talent retention.

Jean-Marie Hiltrop (1999) analyzes HR policies and practices of 115 multinational and 204 domestic companies located in Western Europe, and the impact of such policies on their capability to attract and retain employees. With the help of an independent group of management consultants, he divides those companies into three groups depending on their ability (superior, average or poor) to attract and retain talented people, and then analyzes whether those differences can be explained by a different use of HR policies. According to his study, companies with a superior ability to attract and retain talented people scored well above those in the average and low ability categories on several HRM factors. Out of eleven different factors, the training factor ranked second in importance when explaining the difference between companies with a superior ability to attract and retain valuable employees and those with an average or poor ability.

Some other studies analyze the impact of training on employee retention not in isolation, but rather by linking the training policy with other HR policies and analyzing the link between the HR system and rotation. These studies (Batt, 2002; Gelade and Ivery, 2003; Guest, Michie, Conway, and Sheenan, 2003; Huselid, 1995; Krueger and Rouse, 1998; Ubeda, 2005) also point to the existence of a positive relation between training policy and lower turnover.

\section{The Mondragon corporation and training policy.}

The Mondragon corporation, whose origins date back to 1956, has now become 
a diversified business group with 85,066 employees $^{3}$, comprising over 260 companies, half of which are cooperatives, belonging to its industrial, finance and distribution divisions. In order to facilitate the corporation's development, Mondragon is backed up by a set of organizations, consisting of a multi-level network of training centers, 12 research centers and supra-structure entities. It had a turnover of 13,819 million euros in 2009 , exporting 3,172 million euros, $59.4 \%$ of the industrial group's production value. It is present in fifteen foreign countries in the shape of 75 productive plants and has its own branches in another nine countries. It is currently the seventh largest Spanish business group. As shown in figure 1, Mondragon is a highly diversified corporation.

Figure 1.- Organizational structure of Mondragon in 2010

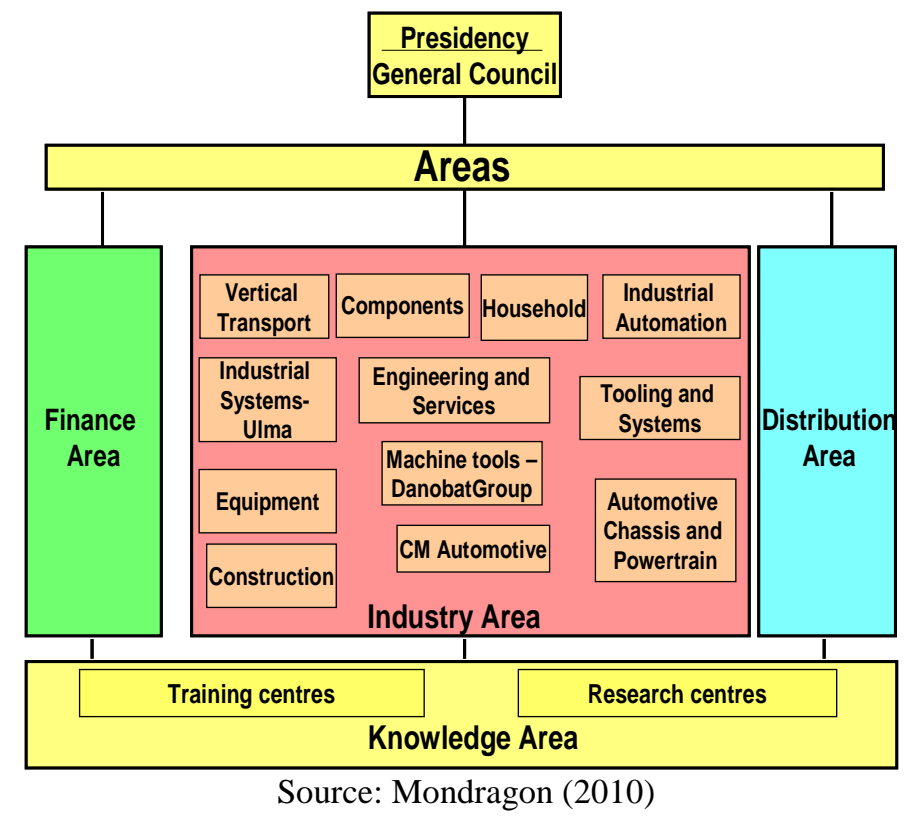

The Mondragon corporation has created several corporate governing bodies (Congress, General Assembly, Governing Council, Divisions...), although it should be noted that each of the cooperatives in the group is a sovereign entity. Mondragon's corporate governing bodies and central services cannot base their power on controlling the cooperatives' assets or shares in the cooperatives' capital, since each cooperative's assets and capital belong to its members. Therefore, the corporation does not own the cooperatives; rather, it is the cooperative members themselves that ultimately vote whether to join or leave the Mondragon corporation.

Membership in the corporation obliges cooperatives to fulfill several commitments, such as the relocation of members from other cooperatives in crisis; a distribution of profits based on solidarity ${ }^{4}$ and reinvestment ${ }^{5}$; the pooling of part of their returns $^{6}$; a uniformity in the initial capital contribution required from new members ${ }^{7}$ and

$338.4 \%$ in the Basque Country, $44.5 \%$ in the rest of Spain and $17 \%$ in the rest of the world (Mondragon, 2010).

$410 \%$ of profits are allocated to the Fund for Cooperative Education and Promotion. This fund promotes the training of members and workers, inter-cooperative relations, and cultural and social welfare programs. Cooperatives earmark $20 \%$ of this fund for the Fund for Inter-Cooperative Education and Promotion, which gives financial support to the corporate training centers.

$545 \%$ of profits are allocated to the cooperative's Reserve Fund. The remaining $45 \%$ is capitalized into each member's account.

${ }_{6}$ Cooperatives must pool between $15 \%$ and $40 \%$ of their returns alongside the rest of cooperatives belonging to the same division (see the specialization areas in Figure 1). In addition, they must earmark 
limitations on managers' salaries.

The salary limitations of managers in Mondragon cooperatives have always been an important source of internal controversy and external debate at Mondragon (Basterretxea, 2008; Basterretxea and Albizu, 2010a; Kasmir, 1996; MacLeod, 1997; Morris, 1992; Thomas and Logan, 1982). In 2008, only 3\% of cooperative members earned a salary higher than 3.5 times that of the lower paid member (Mondragon, 2009, p.52) and, in most cooperatives, the salary of the top manager is still limited to 4.5 times more than that of the lowest paid cooperative member (Basterretxea and Albizu, 2010a). Those limited wage differentials make it difficult to attract and retain managers and highly valuable professionals.

From its beginnings, the active training policy of the Mondragon group has constituted one of its most distinctive characteristics. As Arizmendiarrieta, founder of the Mondragon project, put it (Ormaechea, 1991, p.44), "it has been said that cooperativism is an economic movement that uses educational action, while the definition could also be altered to affirm that it is an educational movement that uses economic action".

Most analyses that set out to explain the successful evolution of the Mondragon Cooperative Experience ascribe a relevant role to the educational centers of the Corporation as a group. This appraisal of corporate training centers as a source of competitive advantage or as a basic explanatory component in the Mondragon success is cited both in the analyses made by the group's founders and successive top managers in different internal publications of the corporation, and in a good number of studies carried out by researchers from outside the Mondragon experience in the 80's and 90's (Asua, 1988; Basterretxea and Albizu, 2010a; Campos, 2005; Ellerman, 1984; Meek and Woodworth, 1990; Morris, 1992; Thomas and Logan, 1991; Whyte and Whyte, 1989).

The Mondragon Corporation has created a complex network of educational centers that comprises a university, various vocational training centers, a business school, a cooperative and management training centre, and even children education centers at primary and secondary levels. This network is complemented by a set of associated companies and entities, which pursue objectives such as the promotion of entrepreneurship, dual training, language teaching or company-applied research. Table 2 attempts to synthesize Mondragon's complex educational framework.

Table 2: Mondragon's complex educational framework

\begin{tabular}{|c|c|c|c|c|c|c|}
\hline & $\begin{array}{l}\text { Students } \\
07 / 08\end{array}$ & $\begin{array}{l}\text { Vocational } \\
\text { Training }\end{array}$ & $\begin{array}{l}\text { Continuous } \\
\text { Vocational } \\
\text { Training }\end{array}$ & $\begin{array}{l}\text { University } \\
\text { Degrees and } \\
\text { Masters }\end{array}$ & $\begin{array}{l}\text { Management } \\
\text { training }\end{array}$ & Others \\
\hline Txoriherri & 764 & 370 & 394 & & & \\
\hline Lea Artibai & 2,830 & 362 & 2,403 & 65 & & \\
\hline Mondragón Univ. & 6,859 & 258 & 2,894 & 3,707 & & \\
\hline Otalora & 2,698 & & & & $2,698(*)$ & \\
\hline Alecop and others & n.a. & & & & & n.a. \\
\hline
\end{tabular}

Source: Own elaboration based on data from Mondragon.

Among the various corporate training centers, a special role is played by Mondragon Unibertsitatea (MU/Mondragon University). This university, officially set

$10 \%$ of their returns for the Mondragon Investment Fund.

7 Historically, new members of Mondragon cooperatives have made an initial contribution to the share capital of no less than the equivalent to the annual salary of the lowest paid member. In 2008, this amounted to 14,000 euros. 
up in 1997, is supported by three educational cooperatives with a long track record: over 50 years of experience within the areas of university qualifications (in Engineering, Business and Humanities) and of Vocational Training (industrial branches). In the educational year 2007/2008, MU had 3,707 pupils signed up for university qualifications, $10 \%$ of whom were studying at third cycle and postgraduate level. Its offer takes in 10 High Level Training Studies, 24 university Degree courses, 21 university Postgraduate courses and 5 third-cycle studies $(\mathrm{PhD})$. In addition, there is a wide offer in continuous training, most of which is made up of short courses generated by demand from companies in the same milieu, mostly Group cooperatives.

The faculties that constitute MU today were home to the first cooperative members within the Mondragon Experience, and were the historical suppliers of technicians, engineers, holders of diplomas and degrees in Business Administration, entrepreneurs and managers for its cooperatives.

MU students have an opportunity to combine their studies with work in the industrial cooperative Alecop, a cooperative within the Mondragon Group created in 1966, whose workforce has, since its foundation, been principally made up of students from the different centers that today form Mondragon University. Thus, more than 7,500 students have combined their studies with part-time work in this cooperative or in other Mondragon cooperatives to which Alecop assigns some of its student-workers. The bodies for management, shareholding, ownership and payment systems are practically the same in Alecop as in the remaining Group cooperatives, which means that the cooperative-based work experience of MU students at Alecop lubricates socialization in cooperative values and the future integration of technicians and university graduates in the Mondragon cooperatives (Asua, 1988; Meek and Woodworth, 1990; Thomas and Logan, 1991; Whyte and Whyte, 1989).

In addition to the university, the Mondragon Group runs specialized vocational training centers (Eskola -MU-, Lea Artibai, Txori Herri) in industrial areas where local cooperatives are operative (circa 1,000 students enrolled in formal vocational training and 5,691 people in continuous vocational training in those centers during the educational year 2007/2008).

Another corporate training center that is of great importance for the cooperative Group is Otalora, the Cooperative and Management Training Center of Mondragon, founded in 1984 for the purpose of training managers and members of social bodies attached to the Mondragon Cooperative Group. Otalora is the training center most closely linked to the specific needs of the Mondragon cooperatives and does not offer any training to people outside the group. It offers a breadth of training designed to facilitate the internal promotion process, improve the competences of company managers, benchmarking and the dissemination of cooperative culture and values among managers and members of the control bodies. Prominent within this training offer is the MBA Executive in Cooperative Company Management. More than 500 executives and managers from Mondragon cooperatives have taken Otalora's MBA, and practically all the current executives in the Group's cooperatives have taken this Master course. In the educational year 2007/2008, Otalora offered Management Training involving 738 people and Cooperative Development training with the attendance of 1,960 people.

The Mondragon cooperatives aid in the funding of MU, Otalora and the Group's vocational training centers. By law, Spanish cooperatives must earmark $10 \%$ of their profits to the Fund for Cooperative Education and Promotion, and Mondragon cooperatives allocate a considerable portion of those funds to the corporate training 
centers $^{8}$. These contributions from cooperatives are the main source of funding for Otalora, the management training center. Vocational training centers are mostly funded by Public Administration, and in the case of MU, it is the students themselves that cover most of its expenses.

Besides contributing to the funding of the training centers, the group's cooperatives play an active role in the bodies that manage and control the centers. The cooperatives that collaborate with corporate training centers have a third of the votes in the General Council and in the training centers' Council. This allows the training content to suit the needs of the cooperatives (Basterretxea, 2008). In any case, the training offered in Mondragon University and in the corporate vocational training centers is not specific to the Mondragon cooperatives and is also valuable for work in firms outside the corporation?.

Mondragon's commitment to training is reflected in the training structures that the corporation has created, as well as in the changes in the cooperative members' qualifications. As shown in table 3, which compares the Industrial Group's training levels in 1987 and 2006, the change has been remarkable. In this period, the group has grown from a workforce that was mainly unskilled or had only basic qualifications to one in which most employees are at least high school graduates or have a vocational training degree.

Table 3.- Distribution of Mondragon Industrial Group members according to training (1987-2006)

\begin{tabular}{|c|c|c|c|c|}
\hline & $\begin{array}{c}\text { Uneducated/ } \\
\text { Basic Education }\end{array}$ & $\begin{array}{c}\text { High School } \\
\text { Graduates }\end{array}$ & $\begin{array}{c}\text { Vocational Training } \\
\text { Degrees }\end{array}$ & University Graduates \\
\hline 1987 & $63 \%$ & $3 \%$ & $23 \%$ & $11 \%$ \\
\hline 2006 & $24.4 \%$ & $6.9 \%$ & $45.1 \%$ & $23.6 \%$ \\
\hline
\end{tabular}

Source: Own elaboration, based on Asua (1988) and Mondragon internal documentation (2010).

This increase in qualifications among members is mainly explained by the fact that a growing number of cooperatives have set a minimum of a vocational training degree as an admission requirement, which has allowed the percentage of vocational training graduates to double in the reference period. The percentage of members with High School qualifications and those with University degrees has more than doubled in that same period.

The continuous training offered by the corporation has also contributed to that higher degree of qualifications. In the early 90's, over 1000 unqualified members earned vocational training degrees through the professional retraining plan implemented by Mondragon in order to facilitate the workforce's multi-skill capability and the relocation of members among cooperatives in times of crisis (Basterretxea and Albizu, 2010b).

\section{Methodology of the investigation}

The survey was carried out with the enterprises in the group. More specifically, the population under study comprises all the cooperatives that were part of the Mondragon Group in the Basque Country and in Navarre (Spain) in December 2006,

\footnotetext{
8 For the allocation of funds in different years, see Basterretxea (2008).

9 According to the Basque Employment Service, Lanbide (2004), nearly $40 \%$ of the engineers from Mondragon University entered a cooperative in 2000 and so did $27 \%$ of those who had completed Management studies. This means that most of the graduates entered a company that did not belong to the group.
} 
with the exception of corporate training centers and cover entities (companies created to provide services to cooperatives in the group). Also excluded were companies that have become members of the corporation over the last five years and had no previous link with the corporate training centers. Accordingly, the population was made up of a total of 81 first degree cooperative companies (cooperative parent companies), 66 of which collaborated with the research by replying to the survey, that is to say, $81.5 \%$ of the population.

The questionnaires, with an accompanying letter, were sent to HR managers in Mondragon, following a pre-test with various cooperative managers. In the cooperatives where this position did not exist, the questionnaire was sent to the company executive manager. Subsequently, the same standardized questionnaire acted as the basis for telephone interviews with the people who had initially been contacted by post. These telephone interviews were carried out between 28 November 2006 and 11 January 2007.

The HR managers' responses were measured using five-point subjective scales ranging from 1 (totally disagree) to 5 (totally agree). The respondents were asked to evaluate their perceptions about the link between Mondragon's training policy and the ability of its cooperatives to attract, develop and retain valuable employees. Many of those subjective perceptions are relative perceptual measures ${ }^{10}$, obtained by asking the respondents to evaluate their ability to attract, develop and retain employees (via training policy), in comparison with the ability of their competitors (e.g. "The continuous training we have provided has enabled us to develop more valuable staff than the staff of our competitors").

Appendix I details the variables, evidence and measures of relative perception of the questionnaire used in the paper. Furthermore, we have also taken into account a series of classification variables in order to find out whether cooperatives that collaborate to a greater degree with Mondragon's corporate training centers and those that put more effort into continuous training perceive greater competitive advantages (see Appendix II).

\section{Results}

Mondragon cooperatives have a preference for collaboration with corporate training centers, and particularly with Mondragon University ${ }^{11} .40$ out of the 66 cooperatives surveyed cite MU as the university they mainly collaborate with. A significant percentage of vocational training graduates and university graduates who work in cooperatives (around 38\% in both cases) come from corporate training centers, although the distribution of these centers is not uniform if we take into consideration the sectors that the companies belong to, the groups they fall into, and their location.

The Mondragon cooperative collective is not homogeneous where the relation with corporate training centers and preferential recruitment from their graduates is concerned. The cooperatives that are geographically closest to the centers and those that belong to the industrial group exhibit the highest rates of collaboration with corporate training centers, and are the most inclined to resort to them when obtaining staff. The remaining cooperatives, particularly those in the retail group, scarcely collaborate with

\footnotetext{
10 While it is true that perceptual data may introduce limitations through increased measurement error and the potential for mono-method bias, the benefits outweigh the drawbacks (Fey et al., 2000). Further, there is precedent for using such perceptual measures in similar research (e.g. Delaney and Huselid, 1996; Fey et al., 2000; Youndt, Snell and Dean, 1996). Additionally, prior research has shown that subjective measures of firm performance are well correlated with objective measures (Geringer and Hebert, 1991; Powell, 1992).

11 See answers to the questions VC1 to VC4 in Appendix II.
} 
the corporate training centers, and their intake of graduates from them is lower. All told, a fourth of the cooperative managers, all of them in cooperatives in the industrial group, come from corporate training centers.

The answers to the questions that measure the effort in continuous vocational training in the cooperatives (VC5 to VC8 in appendix II) show a major commitment to training. Comparing our results with those of the Continuing Vocational Training Survey coordinated by Eurostat in 2005 and presented in $2008^{12}$, we find that Mondragon cooperatives put considerably more effort into the continuous training of their employees than Spanish and European firms of a similar size. In 2006, investment in continuous training in Mondragon cooperatives represented an average of $2.87 \%$ of the total wage bill ${ }^{13}$. This $2.87 \%$ on training outlay as a percentage of labor costs more than doubles the average for Spanish companies, which is situated at 1.2\%; it significantly surpasses the $1.6 \%$ average for companies in the EU-27, and it lies among the average percentages for the companies in the European countries that are most committed to continuous training. This higher training input is also reflected in a higher proportion of employees who benefit from training (50.5\% against 33\% in the EU-27) and in more hours of training per employee (23.74 hours, against the average of 12 for the EU-27). The greatest differences in training input between the Mondragon cooperatives and Spanish and European companies are found in the segment of small and medium businesses, which includes $65 \%$ of the cooperatives in our sample.

Only $23 \%$ of the continuous training of cooperative workers takes place in corporate training centers. When the recipients of continuous training are cooperative managers, the training is based to a greater degree in corporate training centers. In fact, $36 \%$ of management training takes place in corporate training centers (Basterretxea, 2008, p.497). Those differences are coherent with the different kind of training provided to workers and managers. Much of the training provided to blue collar cooperative members is generic, in order to foster the multi-skill capability of workers and their relocation among different cooperatives in case of crisis (Basterretxea and Albizu $2010 \mathrm{~b}$ ). On the other hand, much of the management training, especially that provided at Otalora, is more specific to the Mondragon cooperatives. This specific training supports the retention of managers, to the extent that such training has more value in Mondragon or in other cooperatives than in other local capitalist firms (Basterretxea and Albizu, 2010a, p.11).

\section{Advantages for attracting valuable staff}

In order to test out if Mondragon's training policy, backed up by its corporate training centers, helps cooperatives to attract valuable staff, questions were formulated covering 7 dimensions. The aggregate results of the responses given by HR managers are shown in figure 2.

\footnotetext{
12 See http://epp.eurostat.ec.europa.eu

13 If we consider Mondragon Corporation as a whole, and not only the cooperatives of the group, the percentage of training expenditure over total personnel costs was much lower this year $(0.6 \%)$. This difference may be due to sample bias in our survey (only $40 \mathrm{HR}$ managers of the cooperatives were able to quantify the percentage in the survey, while virtually everyone knew the percentage of employees who had been trained, or the number of training hours per employee). This divergence of figures may also be explained by a high concentration of training expenditure in the cooperatives of the group, while spending on training is much smaller in subsidiaries.
} 
Figure 2.- Response frequencies for the variables that denote Mondragon's perceived competitive advantage in staff attraction.

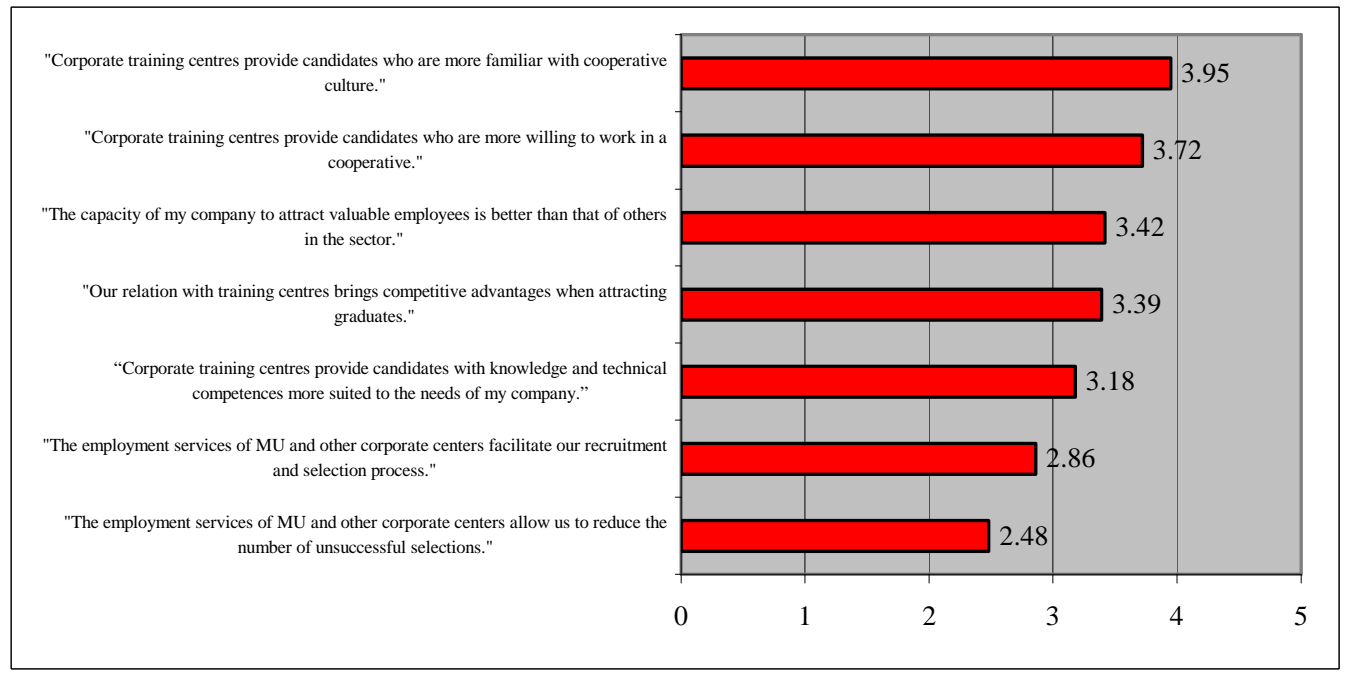

$76.6 \%$ of HR managers agree that cooperative training centers produce staff who is more familiar with cooperative culture, while $12 \%$ are indifferent and only $10.9 \%$ disagree. The data analyzed, therefore, allow us to affirm that the group's training centers fulfill a socializing function of cooperative values among students. These values constitute one of the relevant factors that have provided the Mondragon Experience with continuity and cohesion. In any case, it should be noted that the HR managers' assessment regarding this question is slightly less positive among those cooperatives with a higher percentage of graduates from corporate training centers, as shown in table 4.

Likewise, Mondragon HR managers consider that candidates from corporate training centers have a more favorable attitude towards joining a cooperative enterprise as workers (53.1\% in agreement, and $17.2 \%$ very much in agreement).

Mondragon cooperatives surpass the barriers to the attraction of valuable staff that are common to Social Economy enterprises. $46.8 \%$ of HR heads are in agreement or totally in agreement that their ability to attract valuable employees is greater than their competitors; $40.3 \%$ express no preference, which may be interpreted as a situation of competitive parity, and only $12.9 \%$ find themselves in a situation of competitive disadvantage.

When asked directly whether their relation with training centers is conducive to obtaining competitive advantages for attracting graduates, more than half of the HR managers surveyed answered affirmatively. The awareness of competitive advantages deriving from the relation with training centers is significantly greater in the collective of industrial cooperatives (3.62 out of 5 against 2.1 for other cooperatives) and in those that mentioned a corporate training centre as the centre they prefer to collaborate with (3.65 against 2.96 for cooperatives that collaborate with other training centers) ${ }^{14}$.

The advantages deriving from technical training that is more suited to the needs of companies are not so visible for the cooperatives surveyed taken as a whole, although they are perceived by a significant percentage of HR heads. $38.7 \%$ are of the opinion that their corporate training centers produce candidates with competences and knowledge that are more in tune with their needs, against $17.7 \%$ who consider the

14 Differences significant to 5\% ( $\mathrm{t}$ test and Chi-square test). 
opposite and $43.5 \%$ who express no preference. The assessment is better in the case of cooperatives that mentioned MU as the university they collaborate with first and foremost (3.34 out of 5, against 2.92 of cooperatives that collaborate with other universities $\left.{ }^{15}\right)$.

When asked whether the employment services of corporate training centers facilitate the cooperatives' recruitment and selection processes, opinion is divided among the companies surveyed (46\% unfavorable, including $19 \%$ absolutely unfavorable, against $42 \%$ completely favorable). The assessment is significantly better in cooperatives that collaborate first and foremost with corporate training centers $(3.28$ out of 5, against 2.17 for the cooperatives that collaborate with other training centers), in industrial cooperatives (3.04 out of 5 against 1.56 for other cooperatives) ${ }^{16}$ and in cooperatives with a higher percentage of graduates in vocational training from corporate training centers (see table 4).

When asked whether the corporate training center's employment services contribute to a reduction in the number of unsuccessful staff selections, the response is negative for $57 \%$ of the HR managers surveyed. Despite this globally negative assessment, the evaluation is again significantly better in cooperatives that collaborate first and foremost with corporate training centers ${ }^{17}$ and in those that belong to the Industrial Group ${ }^{18}$.

\section{Advantages for retaining valuable staff}

Figure 3 shows the average values of the responses Mondragon HR managers gave to questions designed to evaluate whether the group's training policy and corporate training centers help cooperatives to retain valuable staff.

Figure 3.- Frequencies of response to the variables that denote perceived competitive advantage of Mondragon in staff retention

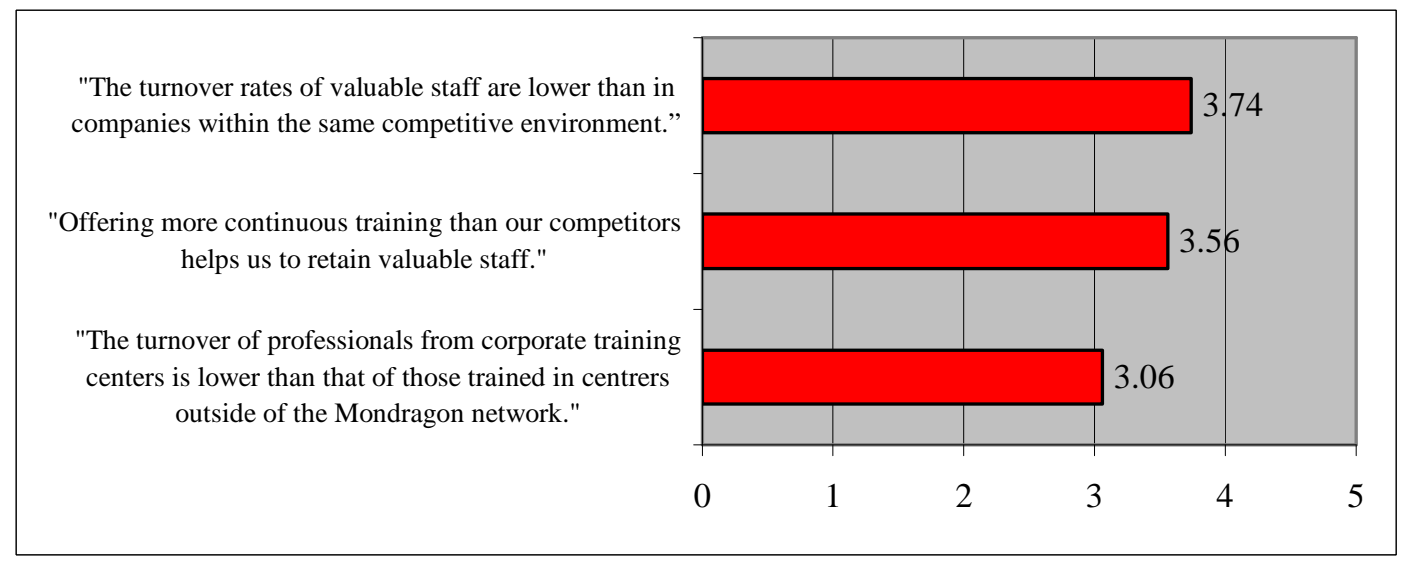

Almost $70 \%$ of Mondragon cooperatives can rely on competitive advantages for the retention of valuable staff when compared with companies in the same competitive environment, while another $17.7 \%$ find themselves in a situation of competitive parity. This advantage vis-à-vis the retention of valuable staff that can be appreciated in this

\footnotetext{
15 Difference significant to 5\% (Chi-square test).

16 Differences significant to $1 \%$ (t test and Chi-square test).

${ }_{17}$ Difference significant to $1 \%$ (t test and Chi-square test).

${ }_{18}$ Difference significant to $5 \%$ ( $\mathrm{t}$ test).
} 
work confirms that Mondragon has been able to overcome the barriers hindering staff retention that have been pointed out in Social Economy literature.

Regarding the degree to which training policy based on corporate training centers helps in the securing of this competitive advantage for retaining valuable staff, we find conflicting evidence.

Lower rates of turnover of valuable staff are correlated with various indicators for training policy based on corporate training centers (See table 4). Thus, cooperatives with a higher percentage of professionals from corporate vocational training centers exhibit lower rates of relative turnover than the rest of the cooperatives. This correlation is positive and significant at $5 \%$. The ability to hold on to valuable staff is also greater the higher the proportion of graduates there are from MU. This correlation is positive and significant at $1 \%$. There are also differences between the cooperatives that have mentioned MU as the university they mostly work with, and all the rest. In the former, the perception of advantages for retaining valuable staff is greater.

Table 4.- Correlation between percentage of professionals that come from corporate training centers and advantages for the attraction and retention of valuable staff

\begin{tabular}{|c|c|c|c|c|}
\hline & & $\begin{array}{l}\text { V2- Corporate training } \\
\text { centres produce } \\
\text { candidates more familiar } \\
\text { with cooperative culture }\end{array}$ & $\begin{array}{l}\text { V5- Employment } \\
\text { services of MU facilitate } \\
\text { our recruitment and } \\
\text { selection }\end{array}$ & $\begin{array}{l}\text { V8- Lower turnover } \\
\text { rates of valuable staff } \\
\text { than competitors }\end{array}$ \\
\hline \multirow{4}{*}{$\begin{array}{l}\text { VC3- \% of graduates } \\
\text { in Vocational Training } \\
\text { from Corporate } \\
\text { training centres }\end{array}$} & Pearson's correlation & $-0.334 * *$ & $0.261 * * *$ & $0.322 * *$ \\
\hline & Kendall's tau-b & $-0.214 * * *$ & 0.182 & 0.188 \\
\hline & Spearman's Rho & $-0.284 * * *$ & 0.234 & 0.228 \\
\hline & $\mathrm{N}$ & 43 & 43 & 42 \\
\hline \multirow{4}{*}{$\begin{array}{l}\text { VC4- } \% \text { of university } \\
\text { graduates from } \\
\text { corporate training } \\
\text { centres }\end{array}$} & Pearson's correlation & $-0.245 * * *$ & 0.147 & $0.452 *$ \\
\hline & Kendall's tau-b & -0.181 & 0.159 & 0.390 \\
\hline & Spearman's Rho & $-0.241 * * *$ & 0.183 & $0.497 *$ \\
\hline & $\mathrm{N}$ & 48 & 47 & 45 \\
\hline $\begin{array}{l}\text { The correla } \\
\text { The correla } \\
\text { The correla }\end{array}$ & $\begin{array}{l}n \text { is significant at } 1 \\
n \text { is significant at } 1 \\
n \text { is significant at } 1\end{array}$ & $\begin{array}{l}0.01 \text { (two-sided test). } \\
0.05 \text { (two-sided test). } \\
0.10 \text { (two-sided test). }\end{array}$ & & \\
\hline
\end{tabular}

Similarly, $62.5 \%$ of Mondragon HR managers consider that their cooperative provides more continuous training than their competitors, and that this commitment to training facilitates the retention of valuable staff.

The perception of competitive advantages for retaining valuable staff is also linked to different indicators of effort put into continuous training by cooperatives. The greater the percentage of employees who have received continuous training over the previous year, and the more hours are devoted to training per employee, the greater the perception of HR managers that they possess advantages for retaining their professionals. These perceived advantages, though, are not correlated with economic investment on continuous training, measured as a percentage of the wage bill that such investment represents (see table 5).

The consideration of continuous training as a factor that reduces the turnover of valuable staff in cooperatives is not determined by such training being given in corporate training centers. In fact, we have not detected a significant correlation between the perception of advantages for retaining valuable staff and the percentage of continuous training provided in collaboration with Mondragon's corporate training centers.

In contradiction with the results that indicate a positive relation between training policy based on corporate training centers and securing advantages for the retention of 
valuable staff, less than a third (32\%) of HR managers surveyed considered that professionals from corporate training centers are more loyal to cooperatives, while the majority expressed no preference with regard to this statement $(43.4 \%)$. It must be stressed that there are no significant differences in this assessment in terms of whether the cooperative collaborates to a greater or lesser degree with the Mondragon training centers, or whether it has a greater or lesser intake of their graduates.

\section{Developing valuable staff}

The averages of the replies to the questions asked to assess whether Mondragon's training policy and training centers help cooperatives to develop valuable staff are reflected in figure 4.

Figure 4.- Frequencies of response to the variables that denote perceived competitive advantage for Mondragon in staff development

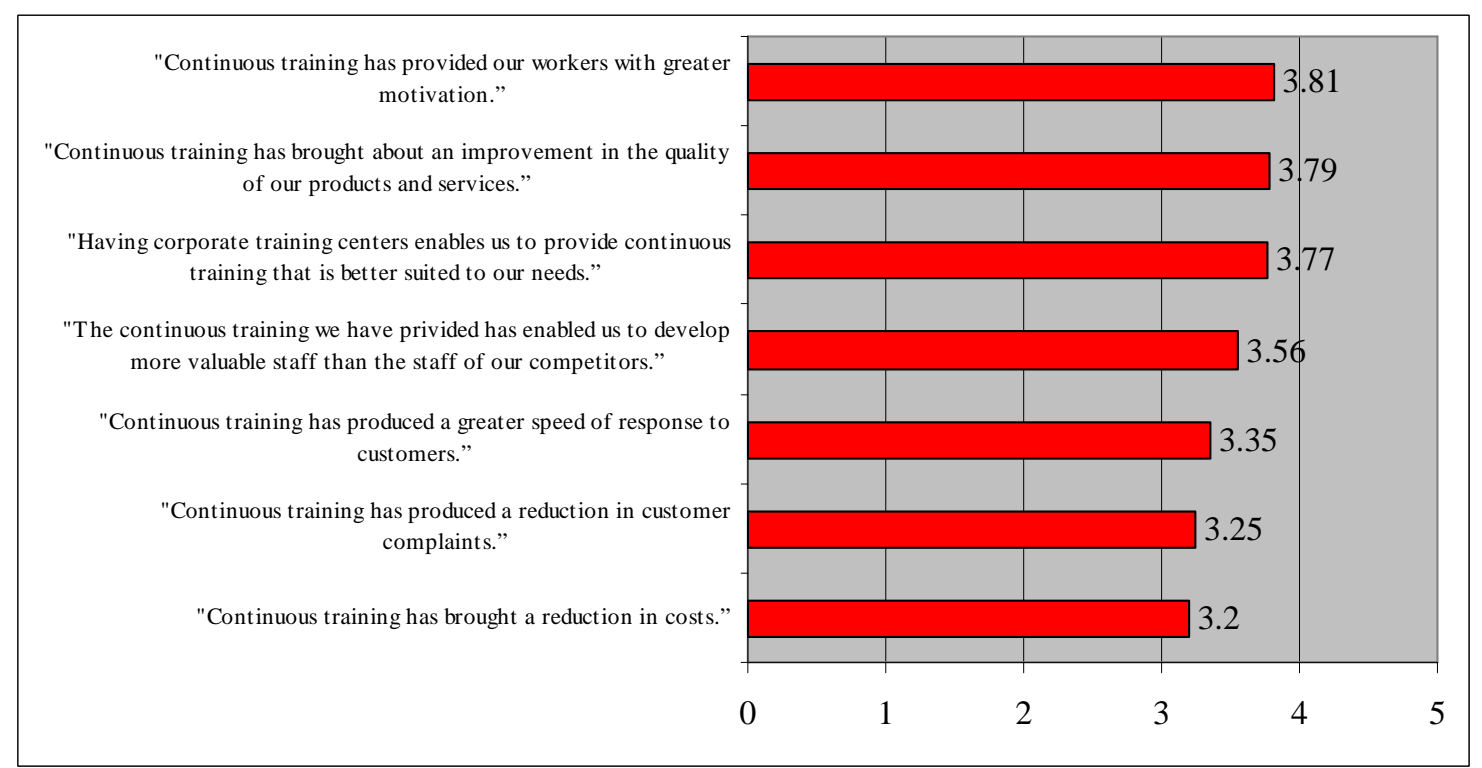

Continuous training has had a positive effect on the motivation of workers, according to $74.6 \%$ of Mondragon heads of HR.

For a vast majority $(76.2 \%)$ of Mondragon HR managers, continuous training has led to better quality in the products and services of their companies. Most of their cooperatives have adopted quality strategies, with a great deal of effort and notable success. What emerges from the results of this survey is that the cooperatives' training policy has been in alignment with the quality strategy, and has had a positive influence on it. The cooperatives that provide training for a greater proportion of employees are the ones that more positively evaluate the effect of training on quality (see table 5). This highly significant positive correlation is due to the fact that the management model and the total quality systems implemented by the Mondragon cooperatives require the active participation of the greatest possible number of employees in continuous improvement.

When the managers were asked whether Mondragon's corporate training centers are conducive to continuous training that is more suited to the needs of the group's companies, more than two thirds $(67.7 \%)$ of the heads of HR at Mondragon were in agreement that this is so. This positive assessment of corporate training centers does not differ in terms of the degree to which the cooperatives collaborate with them in order to 
provide their employees and their managers with continuous training.

As well as producing more motivated staff, more than half of those surveyed (54.2\%) consider that continuous training has enabled their cooperatives to develop more valuable staff than their competitors. This perceived competitive advantage increases the higher the percentage of employees take part in continuous training actions (see table 5).

Table 5.- Correlation between indicators of effort on continuous training and advantages in the development of valuable staff

\begin{tabular}{|c|c|c|c|c|c|c|c|}
\hline & & $\begin{array}{l}\text { V8 Lower } \\
\text { turnover rates } \\
\text { of valuable } \\
\text { staff than } \\
\text { competitors }\end{array}$ & $\begin{array}{l}\text { V12 } \\
\text { Cont.Training } \\
\text { enabled more } \\
\text { valuable staff } \\
\text { than } \\
\text { competitors } \\
\end{array}$ & $\begin{array}{l}\text { V14 Cont. } \\
\text { Training has } \\
\text { brought } \\
\text { a reduction in } \\
\text { costs }\end{array}$ & $\begin{array}{l}\text { V15 Cont. } \\
\text { Training } \\
\text { produced } \\
\text { greater speed } \\
\text { of response to } \\
\text { customers } \\
\end{array}$ & $\begin{array}{l}\text { V16 Cont. } \\
\text { Training } \\
\text { produced } \\
\text { reduction in } \\
\text { customer } \\
\text { complaints }\end{array}$ & $\begin{array}{l}\text { V17 Cont. } \\
\text { Training } \\
\text { brought } \\
\text { improvement } \\
\text { in quality }\end{array}$ \\
\hline \multirow{4}{*}{$\begin{array}{l}\text { VC5 \% Training } \\
\text { expense/ wage } \\
\text { costs }\end{array}$} & $\begin{array}{l}\text { Pearson's } \\
\text { correlation }\end{array}$ & -0.070 & 0.197 & 0.003 & 0.048 & 0.179 & 0.088 \\
\hline & Kendall's tau-b & 0.050 & 0.107 & 0.020 & 0.066 & 0.187 & 0.077 \\
\hline & Spearman's Rho & 0.068 & 0.133 & 0.023 & 0.073 & 0.230 & 0.092 \\
\hline & $\mathrm{N}$ & 39 & 41 & 41 & 42 & 40 & 42 \\
\hline \multirow{4}{*}{$\begin{array}{l}\text { VC6- Rate of } \\
\text { participation of } \\
\text { employees in } \\
\text { Cont. Training }\end{array}$} & $\begin{array}{l}\text { Pearson's } \\
\text { correlation }\end{array}$ & $0.239 * * *$ & $0.408^{*}$ & $0.385^{*}$ & $0.569 *$ & $0.508^{*}$ & $0.469^{*}$ \\
\hline & Kendall's tau-b & $0.188 * * *$ & $0.342 *$ & $0.318^{*}$ & $0.468 *$ & $0.419^{*}$ & $0.379 *$ \\
\hline & Spearman's Rho & $0.232 * * *$ & $0.406^{*}$ & $0.388^{*}$ & $0.566^{*}$ & $0.510^{*}$ & $0.466^{*}$ \\
\hline & $\mathrm{N}$ & 62 & 59 & 62 & 63 & 60 & 63 \\
\hline \multirow[t]{4}{*}{$\begin{array}{l}\text { VC7- Training } \\
\text { hours/employee }\end{array}$} & $\begin{array}{l}\text { Pearson's } \\
\text { correlation }\end{array}$ & $0.388^{*}$ & 0.0850 & -0.1616 & 0.0691 & 0.0671 & 0.1227 \\
\hline & Kendall's tau-b & $0.318^{*}$ & 0.0502 & -0.0529 & 0.0853 & 0.1150 & 0.1536 \\
\hline & Spearman's Rho & $0.404 *$ & 0.0609 & -0.0763 & 0.1089 & 0.1397 & 0.1883 \\
\hline & $\mathrm{N}$ & 53 & 53 & 51 & 53 & 51 & 53 \\
\hline \multirow{4}{*}{$\begin{array}{l}\text { VC8.- \% Cont. } \\
\text { Training } \\
\text { provided with } \\
\text { corporate } \\
\text { training } \\
\text { centres. }\end{array}$} & $\begin{array}{l}\text { Pearson's } \\
\text { correlation }\end{array}$ & 0.170 & 0.073 & $0.223 * * *$ & 0.009 & 0.143 & 0.165 \\
\hline & Kendall's tau-b & 0.143 & 0.111 & $0.213 * *$ & 0.100 & 0.152 & 0.191 \\
\hline & Spearman's Rho & 0.181 & 0.142 & $0.269 * *$ & 0.136 & 0.199 & 0.238 \\
\hline & $\mathrm{N}$ & 60 & 59 & 60 & 62 & 60 & 62 \\
\hline
\end{tabular}

* The correlation is significant at level 0.01 (two-sided test).

** The correlation is significant at level 0.05 (two-sided test).

*** The correlation is significant at level 0.10 (two-sided test).

A significant percentage, though not the majority, of the HR managers consulted consider continuous training to have had a positive effect on greater customer satisfaction. Specifically, $44.5 \%$ of those surveyed state that training has facilitated a more rapid response to customer requirements, and $39.3 \%$ that training has brought about a reduction in the number of such complaints. Once again, the factor that best explains why continuous training leads to better customer service is the fact that training is offered to a greater proportion of employees (see table 5).

For $37.7 \%$ of the managers interviewed, continuous training has contributed to a reduction of costs. This cost decrease due to permanent training is particularly perceived in cooperatives that extend their continuous training program to a greater percentage of their employees, and in those that rely more on corporate training centers to cover their continuous training needs.

\section{Discussion}

The Mondragon cooperatives overcome the barriers against attracting valuable staff that are common to Social Economy enterprises and, in the main, evaluate their 
situation as one of parity or of competitive advantage in relation to companies in their sectors in terms of being able to attract valuable employees.

Mondragon's training policy, backed up by its corporate training centers, is internally seen as a source of competitive advantages for attracting valuable staff, fundamentally due to a supply of candidates who are more socialized in cooperative culture and more inclined to want to work in cooperatives. These perceived advantages generated by corporate training centers are confined to the cooperatives in the Industrial Group.

Mondragon's HR managers consider that continuous training policy produces more motivated and more valuable staff than is the case for competitors. They also consider that continuous training has led to improvements in quality and, to a lesser extent, a reduction in costs and better customer service.

The perceived competitive advantages deriving from continuous training in the Mondragon cooperatives are positively correlated with the percentage of employees receiving such training. However, we have not found a correlation with other indicators of effort on continuous training, such as the number of hours of training per employee, or training budget in relation to wage costs.

The Mondragon cooperatives evaluate their situation, in the main, as one of competitive advantage with regard to companies in their field when it comes to holding on to valuable staff. Such perceived competitive advantage is to a large extent explained by the formula of offering more continuous training provision than their competitors. It is not clear, however, that the training background of workers (cooperative vs. noncooperative training centers) is directly related to the propensity of workers to move on to other employment.

The link between the provision of training and retention can be explained, in the case of training provided to managers, by its high specificity. This specific training supports the retention of managers, to the extent that such training has more value in Mondragon cooperatives than in investor-owned firms. In the case of the training provided to blue collar cooperative members, training is more general than in investorowned firms. This general training fosters the multi-skill capability of the workforce and makes it easier to relocate members in different jobs and cooperatives in times of crisis (Basterretxea and Albizu, 2010a, 2010b). Thus, general training provided to workers enhances job security. Since job security is the most valued factor by cooperative members in the employee satisfaction surveys carried out in Mondragon (Basterretxea, 2008), we can suggest that general training enhances employee retention when it generates a higher degree of employment security.

The link between training and retention can also be explained by the internal promotion that follows many training processes. This is especially true in the case of training provided to managers, since management training and promotion policies are regarded as inseparable policies in Mondragon.

Another factor that can explain the retention of employees after training is the existence of exit barriers. Anyone seeking membership in a Mondragon cooperative is aware of the risk of losing part of the initial contribution to the cooperative's share capital and the subsequent accumulated dividends if they leave the cooperative. A fraction of their initial capital contribution (up to 20\%) goes straight into the cooperative's Reserve Fund, and is not refundable on an individual basis in any case. Besides, when members leave, the cooperative can deduct considerable sums from their initial contribution and from their account's accumulated dividends, a deduction which will vary according to how much the cooperative invested in the member's training (Gorroñogoitia, 1991; Larrañaga, 1991). 
The time factor and asset mass efficiency constitute barriers against any imitation of the Mondragon corporate training centers. The combined effect of time compression diseconomies, experience economies and time flow trajectories make the time factor an important obstacle for any competitor wishing to create a corporate training centre structure or mechanisms for company-centre cooperation as efficient as those created by Mondragon over decades.

A training policy based on corporate training centers, which provides Mondragon cooperative companies with so many perceived advantages, may also be a source of competitive disadvantages in the future because of the specificity of resources involved. The Mondragon network of corporate training centers (and the degrees and diplomas they provide) has its roots to a large extent in the historical needs of industrial cooperatives in the field of human resources. This specificity means that some cooperatives that are in a process of expansion, such as those in the Retail Group, have historically benefited little from the corporate training centers.

Likewise, this specificity acts as a hindrance to the corporate training centers being able to provide assistance in launching and driving some of the new business lines that Mondragon aims to give impetus to in its present strategic reorientation. This calls into question some aspects of the training policy that has been pursued until now, and suggests that the corporation should reconsider the keystones of its relation with the corporate training centers.

This paper contributes to the literature on the educational fabric of Mondragon adding updated empirical evidence to previous studies and incorporating the point of view of HR managers of the group's cooperatives. Our results show that Mondragon HR managers consider that the corporate training policy and training centers generate many advantages, but we have also found such advantages to be more moderate than those cited in the historical literature on Mondragon.

The broader source of data and opinions of the present study shows a less homogeneous link between corporate training centers and cooperatives than in previous studies. Likewise, we have found that some sources of advantage according to previous literature (technical training more suited to the needs of cooperatives, training centers as facilitators of recruitment, lower rotation of graduates in corporate training centers) are not perceived by the cooperatives' HR managers.

With respect to the contribution of this paper to the literature on training policy, the paper's findings show that training policy and corporate training centers can be conceived by HR managers as a source of advantages for the attraction, development and retention of staff. Most studies on training policy analyze the impact of training on business results, but there are few studies that explore the link between training and employee attraction and retention. The paper's findings, in particular those regarding the effect of training on worker attraction and retention, add empirical evidence to the few studies on the subject. Besides, our results suggest that training policy can have a positive impact on employee attraction and retention in a context of serious limitations and particularities in other HR policies, such as wage policy.

Other large business corporations that are presently thinking of making a commitment to strengthening their training structures or creating corporate training centers on the same lines as those analyzed in this work would have to take into account that such a move only makes sense in interconnection with other HR policies. In the experience that has been analyzed here, high investment in training takes on more meaning when internal job markets and extensive job ladders exist in each cooperative and in the corporation. Moreover, this is a corporation in which business culture is the main point of union between the cooperatives that form it, which demands extra input 
into corporate culture training. Another feature of this corporation's HR policy is the existence of wage limitations, and such a restriction stands in the way of using pay as a preferential means of attracting and retaining valuable staff. In companies where business culture is not so important, where the possibilities of promotion are relatively slim, and where it is easy to attract and retain talent with competitive wages, it probably does not make sense to set up a corporate university and other training centers similar to those analyzed in this study.

Finally, any possible imitator would have to be aware of the high cost that could be incurred by the creation of a training centre structure similar to that of Mondragon. In the case we have studied here, this cost is, to a large extent, defrayed as a result of the favorable tax treatment that is accorded in Spain to investments by cooperatives on continuous training and on their corporate training centers. Consequently, even if a competitor were to develop continuous training programs and corporate training centers as valuable as those of Mondragon, the costs the competitor would have to incur would cancel out part or all of that value.

\section{Limitations}

The main limitations of the study stem from the subjectivity of the data used (opinions of HR managers about the effectiveness of training policies). This subjectivity bias can be especially important in those questions in which HR managers evaluate training policies that they have themselves supported or implemented (continuous training policies in the main). In order to reduce this subjectivity, it would be interesting to conduct further research to learn what kind of answers to the same questions would be provided by workers.

Another limitation is that we have not considered possible reverse causality relationships. In some questions in which most HR managers strongly disagreed with some factors as a source of advantages (for example, when asked if MU employment services facilitate their recruitment process), we have highlighted that those cooperatives with a higher degree of collaboration with corporate training centers had a more positive point of view. In those questions, there could also be reverse causality: the negative assessment of most of HR managers on some features of Mondragon training centers (e.g. their employment services) may explain a lower degree of collaboration with such centers.

\section{Acknowledgements}

We would like to thank the referees and the editor for their helpful and inspiring comments.

\section{APPENDIX I}

The variables included in the questionnaire are the following:

V1- "The capacity of my company to attract valuable employees is better than that of others in the sector."

V2- "Corporate training centers produce candidates who are more familiar with cooperative culture."

V3- "Corporate training centers produce candidates who are more willing to work in a cooperative."

V4- "Corporate training centers produce candidates with knowledge and technical competences more suited to the needs of my company."

V5- "The employment services of MU and other corporate centers facilitate our recruitment and selection 
process."

V6- "The employment services of MU and other corporate centers allow us to reduce the number of unsuccessful selections."

V7.- "Our relation with training centers provides us with competitive advantages when attracting graduates."

V8- "The turnover rates of valuable staff are lower than in companies within the same competitive environment."

V9- "The turnover of professionals from corporate training centers is lower than that of those trained in centers outside of the Mondragon network."

V10- "Offering more continuous training than competitors helps us to retain valuable staff."

In order to measure whether continuous training produces more valuable staff, in addition to the perceptions of HR managers, we included a series of indirect indicators that are usually applied in scientific literature evaluating the efficiency of company training activities. These indicators indirectly measure whether training produces more valuable staff, via the consumer's value perceptions. Thus, continuous training produces more valuable staff, if the latter are able to produce better quality results, providing better customer service, or contributing to a reduction in costs.

Therefore, the variables included to test this question are the following:

V11- "Having corporate training centers enables us to provide continuous training that is better suited to our needs."

V12- "The continuous training we have provided has enabled us to develop more valuable staff than the staff of our competitors."

V13- "Continuous training has provided our workers with greater motivation."

V14- "Continuous training has brought a reduction in costs."

V15- "Continuous training has produced a greater speed of response to customers."

V16- "Continuous training has produced a reduction in customer complaints."

V17- "Continuous training has brought about an improvement in the quality of our products and services."

\section{APPENDIX II}

Classification variables:

VC1- Priority collaboration with corporate vocational training centers.

VC2- Priority collaboration with Mondragon Unibertsitatea.

VC3- \% of graduates in vocational training from corporate training centers.

$\mathrm{VC} 4-\%$ of university graduates from corporate training centers.

VC5- \% training expense/wage costs.

VC6- Rate of participation of employees in continuous training.

VC7- No. of hours of training/employee.

VC8 - \% continuous training provided in corporate training centers.

\section{References}

Agirre, A. (2001). Los principios cooperativos "atractores" de la gestión eficiente: su medición. Aplicación al caso de Mondragón Corporación Cooperativa. CIRIEC-España, Revista de Economía Pública, Social y Cooperativa, 39(11), 93-113.

Albizu, E., \& Basterretxea, I. (1998). Flexibilidad laboral y generación de empleo en tiempos de crisis. El caso de Mondragón Corporación Cooperativa. Revista Europea de Dirección y Economía de la Empresa, 7(3), 83-98.

Aranzadi, D. (2003). El significado de la Experiencia Cooperativa de Mondragón. Estudios Empresariales, 112(2), 58-69. 
Asua, B. (1988). Educación y trabajo en la sociedad industrial del País Vasco. La "Eskola Politécnica José María Arizmendiarreta" en el Grupo Cooperativo Mondragón. Unpublished Ph. Doctoral Thesis. Leioa: University of the Basque Country.

Barney, J.B., \& Wright, P.M. (1998). On becoming a strategic partner. The role of human resources in gaining competitive advantage. Human Resource Management, 37(1), 31-46.

Barron, P. (2008). Education and talent management: implications for the hospitality industry. International Journal of Contemporary Hospitality Management, 20(7), 730742.

Basterretxea, I. (2008). La política de formación como fuente de ventaja competitiva en la experiencia Mondragón. Un análisis desde la visión basada en los recursos. Unpublished Ph. Doctoral Thesis. Bilbao: University of the Basque Country.

Basterretxea, I., \& Albizu, E. (2010a). Management training as a source of perceived competitive advantage: the Mondragon Cooperative group case. Economic and Industrial Democracy. October, 25. doi:10.1177/0143831X10377809

Basterretxea, I., \& Albizu, E. (2010b). ¿Es posible resistir a la crisis? Un análisis desde la gestión de las políticas de empleo y formación en Mondragón. CIRIEC-España, Revista de Economía Pública, Social y Cooperativa, (67), 75-96.

Batt, R. (2002). Managing Customer Services: Human Resource Practices, Quit Rates, and Sales Growth. Academy of Management Journal, 45(3), 587-597.

Bayo, A., \& Merino, J. (2000). Human resource management and operational performance in Spanish manufacturing industry. Working Paper 43/00, Pamplona: Public University of Navarra.

Bayo, A., \& Merino, J. (2001). Size and HRM in the Spanish manufacturing industry. Employee Relations, 23(2), 188-206.

Boxall, P., \& Purcell, J. (2003). Strategy and Human Resource Management. Palgrave Macmillan: Basingstoke.

Bradley, K., \& Gelb, A. (1985). Cooperation at Work: The Mondragon Experience. Heinemann: London.

Campos, R.S. (2005). Mondragon Unibertsitatea: entre Universidade e Formaçao Profissional. Revista Urutágüa-Revista académica multidisciplinar, (6), Universidade Estadual de Maringá. Retrieved from http://www.uem.br/urutagua/006/06campos.htm.

Capelli, P. (2008). Talent Management for the twenty-first century, Harvard Business Review, 86(3), 74-81.

CEDEFOP (2010). Employer-provided vocational training in Europe: evaluation and interpretation of the third continuing vocational training survey. Luxembourg: Publications Office of the European Union. 
Charterina, J., Albizu, E., \& Landeta, J. (2007). The quality of management in Basque companies: differences existing between cooperative and non-cooperative companies. In S. Novkovic \& V. Sena (Eds.), Advances in Economic Analysis of Participatory and Labor-Managed Firms. Cooperative Firms in Global Markets: Incidence, Viability and Economic Performance, 10 (pp. 109-150). New York: Elsevier Science.

Chaves, R. (2003). El modelo cooperativo de Mondragón. El desarrollo económico basado en el cooperativismo. In R. Chaves, J.L. Monzón \& A. Sajardo (Eds.), Elementos de economía social. Teoría y realidad (pp. 93-106). Valencia: University of Valencia.

Cheney, G. (1999). Values at work: employee participation meets market pressure at Mondragón. Ithaca, NY: ILR Press.

Clamp, C.A. (2000). The internationalization of Mondragon. Annals of Public and Cooperative Economics, 71(4), 557-577.

Delaney, J.T., \& Huselid, M.A. (1996). The impact of human resource management practices on perceptions of organizational performance. Academy of Management Journal, 39(4), 949-969.

Ellerman, D.P. (1984). Entrepreneurship in the Mondragon Cooperatives. Review of Social Economy, (42), 272-294.

Fegley, S. (2006). 2006 Talent Management Survey Report, SHRM Research Quarterly. Alexandria, VA.

Fey, C.F., Björkman, I., \& Pavlovskaya, A. (2000). The Effect of Human Resource Management Practices on Firm Performance in Russia. International Journal of Human Resource Management, 11(1), 1-18.

Gelade, G.A., \& Ivery, M. (2003). The Impact of Human Resource Management and Work Climate on Organizational Performance. Personnel Psychology, 56(2), 383-404.

Geringer, M.J., \& Herbert, L. (1991). Measuring Performance of International Joint Ventures. Journal of International Business Studies, (28) 249-63.

Gorroñogoitia, A. (1991). La organización interna de una cooperativa. Textos básicos de Otalora. Chapter III, Mondragón: Otalora.

Guest, D., Michie, J., Conway, N., \& Sheenan, M. (2003). Human Resource Management and Corporate Performance in the UK. British Journal of Management, 41(2), 291-314.

Hay, M. (2002). Strategies for survival in the war of talent. Career Development International, (1), 52-55.

Hiltrop, J.M. (1999). The quest for the best: human resource practices to attract and retain talent. European Management Journal, 17(4), 422-440.

Hoover, K.R. (1992). Mondragon's answers to utopia's problems. Utopian Studies, 3(2), $1-19$. 
Hughes, B. (2009). What will it take to keep our best people. Sydney: Macquarie Graduate School of Management's Executive Education.

Huselid, M.A. (1995). The Impact of Human Resource Management Practices on Turnover, Productivity and Corporate Financial Performance. Academy of Management Journal, 8(3), 635-672.

Jacobsen, G. (2001). Cooperative and training dimensions in entrepreneurship. A study of the methodology of the Saiolan Centre in Mondragon. Inussuk. Artic Research Journal, (1), 137-146. Retrieved from http://http://cog.kent.edu/lib/JakobsenCoop.htm

Kasmir, S. (1996). The myth of Mondragon: cooperatives, politics, and working-class life in a Basque town. New York: State University of New York Press.

Krueger, A., \& Rouse, C. (1998). The effect of workplace education on earnings, turnover and job performance. Journal of Labor Economics, 16(1), 61-94.

Lanbide (2004). Mondragon Unibertsitatea. Encuesta de inserción laboral de titulados y tituladas. Promoción 2000. Vitoria-Gasteiz: Lanbide.

Larrañaga, J.M. (1991). El socio cooperativista. Textos básicos de Otalora. Chapter IV, Mondragón: Otalora.

Logan, C.G. (1988). An experiment that continues: the Mondragon co-operatives. In Congreso sobre el cooperativismo y la economía social en el mundo. II Congreso Mundial Vasco (pp. 111-113). Vitoria-Gasteiz: Publishing Service of the Basque Government.

MacLeod, G. (1997). From Mondragon to America: Experiments in Community Economic Development. Sidney: University College of Cape Breton Press.

Meek, C.B., \& Woodworth, W.P. (1990). Technical training and enterprise: Mondragon's educational system and its implications for other cooperatives. Economic and Industrial Democracy, (11), 508-528.

MCC (2000). Balance de situación del Plan de Reciclaje Profesional de Mondragón Corporación Cooperativa. Mondragón: Mondragón.

Mondragon (2009). 2008 Annual Report. Mondragón: Mondragón.

Mondragon (2010). 2009 Annual Report. Mondragón: Mondragón.

Morris, D. (1992). The Mondragon System: Cooperation at Work, Institute for Local Self-Reliance, Washington, DC. (http://www.newrules.org/resources/MondragonCoop.pdf)

Mueller, F. (1996). Human Resources as Strategic Assets: An Evolutionary ResourceBased Theory. Journal of Management Studies, 33(6), 757-785.

Ormaetxea, F. (1991). Eskola Politeknikoa Jose Maria Arizmendiarreta. Sdad. Coop. Textos básicos de Otalora. Aretxabaleta: Otalora. 
Powell, T.C. (1992). Organizational Alignment as a Competitive Advantage, Strategic Management Journal, (13), 119-34.

Smith, S.C. (2001). Blooming together or wilting alone? Network Externalities and the Mondragon and La Lega cooperative networks. Helsinki: United Nations University/WIDER Discussion Paper No 2001/27.

Thomas, H., \& Logan, C. (1982). Mondragon, an economic analysis, Winchester, MA: Allen \& Unwin.

Úbeda, M. (2005). Training and business performance: the Spanish case. International Journal of Human Resource Management, 16(9), 1691-1710.

Whyte, W.F., \& Whyte, K.K. (1989). Making Mondragón. Ithaca, NY: ILR Press.

Wright, P.M., McManaman, G.C., \& McWilliams, A. (1994). Human Resources and sustained competitive advantage: A Resource-Based perspective. International Journal of Human Resource Management, 5(2), 301-326.

Youndt, M.A., Snell, S.A., \& Dean, J.W. (1996). Human resource management, manufacturing strategy, and firm performance. Academy of Management Journal, 39(4), 836-866. 